\title{
Tribological Behaviour and Lubricating Mechanism of Tire Pyrolysis Oil
}

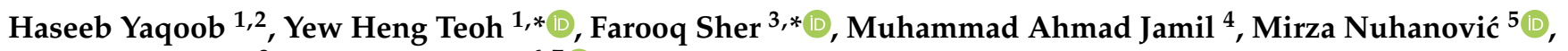 \\ Omid Razmkhah ${ }^{3}$ and Begum Erten ${ }^{6,7}$ (i)
}

1 School of Mechanical Engineering, Engineering Campus, Universiti Sains Malaysia, Nibong Tebal, Penang 14300, Malaysia; haseeb.yaqoob@student.usm.my

2 Department of Mechanical Engineering, Khwaja Fareed University of Engineering and Information Technology, Rahim Yar Khan 64200, Pakistan

3 School of Mechanical, Aerospace and Automotive Engineering, Faculty of Engineering, Environmental and Computing, Coventry University, Coventry CV1 5FB, UK; O.Razmkhah@coventry.ac.uk

4 Department of Mechanical and Construction Engineering, Northumbria University, Newcastle Upon Tyne NE1 8ST, UK; ahmed_jamil@live.com

5 Department of Chemistry, Faculty of Science, University of Sarajevo, 71000 Sarajevo, Bosnia and Herzegovina; mirzanuhanovic1.0@gmail.com

6 Department of Occupational Health and Safety, Gedik Vocational School, İstanbul Gedik University, İstanbul 34876, Turkey; Begum.Erten@gedik.edu.tr

7 International Society of Engineering Science and Technology, Engineering \& Computing Building, Coventry University, 24 Oxford St, Coventry CV1 5EH, UK

* Correspondence: yewhengteoh@usm.my (Y.H.T.); Farooq.Sher@coventry.ac.uk or Farooq.Sher@gmail.com (F.S.)

check for updates

Citation: Yaqoob, H.; Teoh, Y.H.; Sher, F.; Jamil, M.A.; Nuhanović, M.; Razmkhah, O.; Erten, B. Tribological Behaviour and Lubricating Mechanism of Tire Pyrolysis Oil. Coatings 2021, 11, 386. https://doi.org/10.3390/ coatings11040386

Academic Editor: Rubén González

Received: 1 March 2021

Accepted: 23 March 2021

Published: 29 March 2021

Publisher's Note: MDPI stays neutral with regard to jurisdictional claims in published maps and institutional affiliations.

Copyright: (C) 2021 by the authors. Licensee MDPI, Basel, Switzerland. This article is an open access article distributed under the terms and conditions of the Creative Commons Attribution (CC BY) license (https:/ / creativecommons.org/licenses/by/ $4.0 /)$.
Abstract: The four-ball tester was used in this analysis to demonstrate the lubricity of tire pyrolysis oil (TPO). The tribological performance of the tire pyrolysis oil was compared with diesel fuel (DF) and their blends, DT10 (TPO 10\%, Diesel 90\%) and DT20 (TPO 20\%, Diesel 80\%). A scanning electron microscope (SEM) was used to investigate the wear scar. In contrast to diesel fuel, TPO demonstrated better antiwear behaviour in terms of higher load-carrying capacity. DT10, DT20, and TPO's wear scar diameter (WSD) was 22.35\%, 16.01\%, and 31.99\% smaller than that of diesel at $80 \mathrm{~kg}$ load, respectively. The scanning electron microscope micrographs showed that the TPO and DT10 had less wear than their counterparts.

Keywords: sustainable materials; tire pyrolysis oil; tribology; wear; lubricity; diesel fuel; sustainable development

\section{Introduction}

Alternative fuels have gained attention in diesel engines [1] because of the rapid depletion of fossil fuels [2], climate change [3], economic challenges, and growth in population and energy demand [4-7]. Though, food-based alternative fuels include palm oil, soybean, sunflower, rapeseed, etc., are criticized worldwide because of deforestation, especially the food-versus-fuel conflict. Subsequently, it is claimed that the transformation of food production to fuel will generate a food shortage globally [8]. Therefore, the waste-to-fuel conversion method has enormous potential that leads to alternative fuel to reduce the pressure on conventional fuel and limit the waste problem $[9,10]$. The waste of solids is a significant problem that leads to environmental and financial problems [11]. The open dumping of waste tires creates a severe threat to the environment and participates in climate change and global warming [12-15].

According to the European Automobile Manufacturers Association (EAMA), there are currently 1.35 billion cars on the road worldwide [16], with two billion planned by 2035 [17]. It is reported that annually 1 billion waste tires are discarded, and about four billion waste tires are currently in storage and dumpsites worldwide [18]. The static stirred 
batch pyrolysis reactor is used to process the waste tires to produce $44 \%$ weight char, $49 \%$ weight oil, and 7\% weight pyrolytic gases [19]. Subsequently, it is possible to purify about $44.5 \%$ of TPO as a fuel [20].

Tire pyrolysis oil (TPO) is formed by the waste vehicle tires' pyrolysis operation, and this is one of the primary waste tire materials. The potential use of tire pyrolysis oil has impressed the investigators to investigate the use of it in boilers [21], furnaces, and compression ignition (CI) engines [22-25] as renewable fuel [26]. The calorific value, kinematic viscosity, and density of the TPO are somewhat close to that of diesel fuel (DF), but the sulphur content is significantly greater than DF [27]. Raw TPO has high sulphur content ranging from $0.55 \%$ to $3.95 \%$ [28]. Therefore, the distillation of TPO is an essential part to lower the sulphur content for its use as a fuel to meet the strict emission level. Nevertheless, the low sulphur content in the fuel decreases its lubricity [29]. However, the TPO drawback seems to be that an up to $90 \%$ blend could be used along with the diesel, alike after its fuel content has been filtered. In diesel engines, the TPO can be used in operating the dual-fuel mode [30].

Yaqoob et al. studied the tribological characteristics of the TPO and their blend with palm oil biodiesel on a four-ball tester. It is revealed that the BT10 ( $90 \%$ biodiesel- $10 \%$ TPO) shows favourable results in terms of wear and friction as compared to BT20, TPO, and biodiesel [31]. Habibullah et al. examined the friction and wear of the Calophyllum inophyllum biodiesel (CIB) and their blends with diesel fuel on a four-ball tester and reported that the friction and wear decrease as the biodiesel concentration and load increase [32]. Mosarof et al. [33] performed the tribological analysis of the Calophyllum inophyllum and palm oil biodiesel (PB) and their blends with DF at varying loads, temperatures, and at a constant speed. With increasing biodiesel concentration, load, and temperature, friction and wear tend to decrease. Mujtaba et al. [34] stated that B30 + ethanol fuel's lubricity decreases, while friction and wear tend to increase among other additives. B30 + dimethyl carbonate (DMC) exhibited a low wear scar diameter (WSD), and $\mathrm{B} 30+$ nanoparticle $\mathrm{TiO}_{2}$ showed the best results with the lowest coefficient of friction and wear scar diameter among other tested fuels. Awang et al. [35] determined the lubricity of the pyrolytic plastic oil (PPO) and reported the lowest coefficient of friction by using the high-frequency reciprocating rig (HFRR) based on the ASTM D6079 standard [36].

Fuel supplies the energy and is used as a lubricant with swift modernization and technological progress $[37,38]$. The engine life majorly depends on the lubricity of the engine. The engine's lubricity reduces friction between moving parts, decreasing energy consumption, and friction strength [39]. In car engines, the fuel lubricates the fuel pump and injector in particular [40]. Engine fuel lubrication is determined by fuel inlet temperature $\left(>60^{\circ} \mathrm{C}\right)$ [41]. Consequently, TPO has gained popularity as a supplement for diesel, and the current demand to conduct research related to the wear and friction characteristics of engine fuel are imperative. To our understanding, there is a great deal of research available on tire oils' combustion, emission properties, and performance in diesel engines [22-26,42-45], but there is no technical study investigating the tribological characteristics of TPO.

The recent research examines the wear and friction characteristics of TPO and its blend with diesel at different testing parameters to concentrate on the gap. TPO, pure diesel, and their blends DT10 (TPO 10\%, Diesel 90\%) and DT20 (TPO 20\%, Diesel 80\%) are explored in this study. In the present study, the experimental study of wear and friction characteristics of the TPO is examined through the four-ball tester (FBT).

\section{System Description and Methodology}

\subsection{Refining and Production of Tire Pyrolysis Oil}

Steel wires and fibres were removed from the automobile tires, and then the tires were cut into small pieces. Waste tire pieces were carried out in a chamber for the pyrolysis technique. The pyrolysis chamber's reaction temperature was changed from 400 to $600{ }^{\circ} \mathrm{C}$ in the high production of liquid tire pyrolysis oil, Murillo et al. [46] verified that $500^{\circ} \mathrm{C}$ was the optimum temperature. The plant supplied the highest liquid oil yield with $49 \mathrm{wt} . \%$, 
solid and gas yields were $44 \mathrm{wt} . \%$ and $7 \mathrm{wt} . \%$, respectively [19]. There is a quite complicated solution of $\mathrm{C}_{5}-\mathrm{C}_{16}$ organic chemicals and a large number of unsaturated compounds in tire pyrolysis oil. The overall aliphatic and aromatic compound concentrations were $42.1 \%$ and $49.8 \%$ by weight, respectively [47].

The waste tire pyrolysis oil was procured from the pyrolysis industry located in Malaysia. The purification process of the waste TPO was carried out in the laboratory. At the start, the waste TPO was heated at $110^{\circ} \mathrm{C}$ to remove the moisture amount. Then, in this waste TPO, $8 \% \mathrm{H}_{2} \mathrm{SO}_{4}$ was utilized to prepare a hydro-sulphuric acid treatment at a temperature of $70^{\circ} \mathrm{C}$ by using a hotplate for four hours. After that process, the mixture was allowed there for $48 \mathrm{~h}$. Finally, that mixture was distilled by using the vacuum distillation unit. After the distillation process, the TPO's sulphur content reduced from $0.87 \%$ to $0.03 \%$. Through this process, TPO was obtained for testing in this experimental study.

The DF was procured from a local company. The magnetic stirrer was used to generate the DT10 and DT20 blends. In this experimental research, the diesel fuel, DT10, DT20, and TPO are used as tested fuel and the main physical properties of the tested fuels are determined and listed in Table 1. The equipment used for this experiment is listed in Table 2.

Table 1. The thermochemical and physical properties of the tested fuels.

\begin{tabular}{ccccc}
\hline Tested Samples & $\begin{array}{c}\text { Density } \\
\left(\mathbf{k g} / \mathbf{m}^{\mathbf{3}} \mathbf{)}\left(\mathbf{1 5}{ }^{\circ} \mathbf{C}\right)\right.\end{array}$ & $\begin{array}{c}\text { Kinematic Viscosity } \\
\left.\left(\mathbf{m m}^{\mathbf{2}} \mathbf{s}\right) \mathbf{( 4 0}{ }^{\circ} \mathbf{C}\right)\end{array}$ & $\begin{array}{c}\text { Lower Heating } \\
\text { Value }(\mathbf{M J} / \mathbf{k g})\end{array}$ & Cetane Index \\
\hline DF & 845.3 & 3.36 & 44.49 & 51.72 \\
DT10 & 849 & 3.17 & 44.81 & 51.71 \\
DT20 & 854 & 2.98 & 44.68 & 51.68 \\
TPO & 946 & 2.23 & 41.81 & 51.65 \\
\hline
\end{tabular}

Table 2. Details of apparatuses and instruments used for the experimental study [31].

\begin{tabular}{cccccc}
\hline Properties/Instruments & Standard/Mode & Apparatus & Made & Model & Accuracy \\
\hline Calorific value & ASTM D240 [48] & Bomb Calorimeter & IKA, Oxford, UK & C2000 & $\pm 0.1 \%$ MJ $/ \mathrm{kg}$ \\
Kinematic viscosity & ASTM D7042 [49] & Stabinger viscometer & Anton Paar, St Albans, UK & SVM 3000 & $\pm 0.35 \%$ \\
Density & ASTM D4052 [50] & Stabinger viscometer & Anton Paar, St Albans, UK & SVM 3000 & $\pm 0.1 \mathrm{~kg} / \mathrm{m}^{3}$ \\
$\begin{array}{c}\text { Wear and friction } \\
\text { Wear scar }\end{array}$ & ASTM D2266 [51] & Four-ball testers & DUCOM, Karnataka, India & TR-30L-IAS & - \\
$\begin{array}{c}\text { diameter (WSD) } \\
\begin{array}{c}\text { Scanning Electron } \\
\text { Microscope (SEM) }\end{array}\end{array}$ & ASTM D4172 [52] & Optical microscope & IKA, Oxford, UK & C2000 & $\pm 0.01 \mathrm{~mm}$ \\
\hline
\end{tabular}

\subsection{Test Arrangement}

A four-ball tester was used in this research study, which helps develop and study innovative lubricants in tribology. This equipment's operation is that four balls were used to evaluate the specimen; however, three balls were locked together in the fuel specimen tub, and one ball was rotating, which carried on the upper end via a collection of electricmotor spindles at a constant speed. The schematic figure of the FBT and the experimental configuration is shown in Figure 1. The inspected fuel was loaded into the fuel tub. The four-ball tester has features listed in Table 3.

The lever was used to implement the load onto the bottom-locked balls, and the frictional torque was calculated through an adjusted arm using the spring attached with the friction recording tool. In such an experiment, balls made of carbon-chromium steel were used, and the balls' specifications are recorded in Table 4 . Four new balls were washed with acetone and then dried with tissue paper and air. 


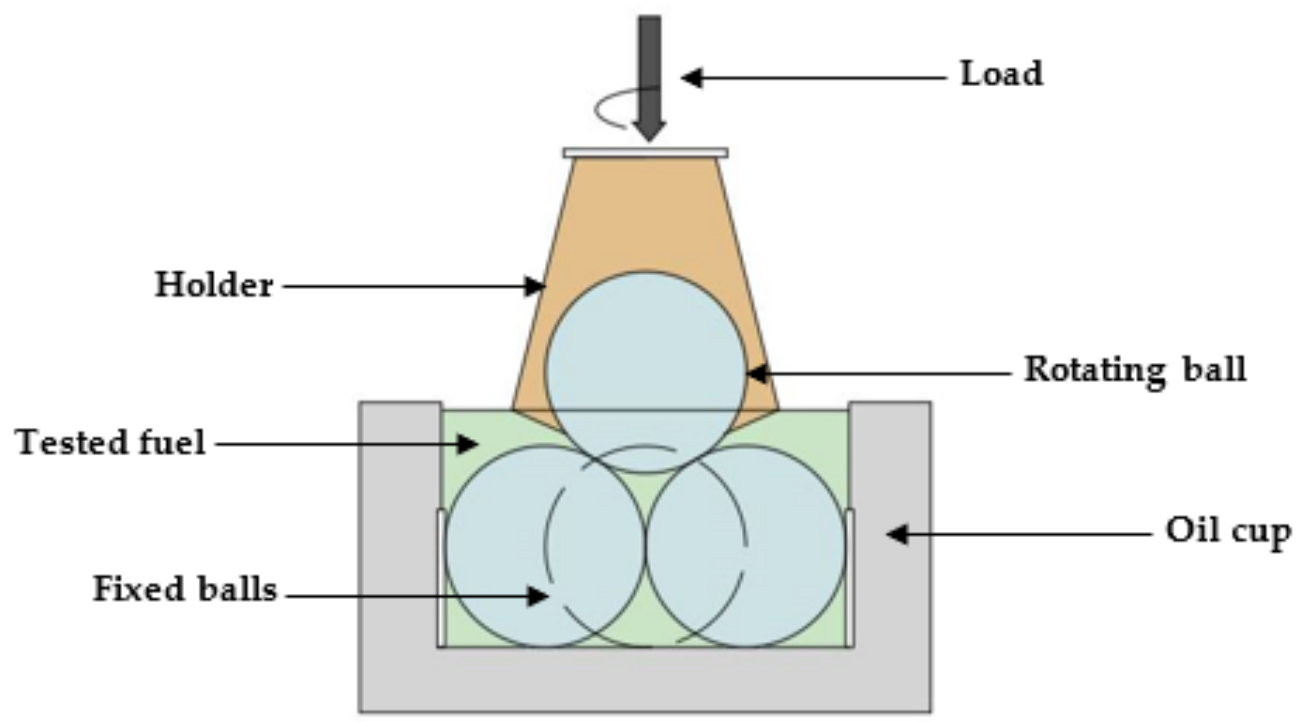

Figure 1. Schematic diagram of the four-ball tribometer [31].

Table 3. Detailed properties of the four-ball tester [31].

\begin{tabular}{cccc}
\hline Specification & Units & Detail & Accuracy \\
\hline Model & - & Make: DUCOMTR-30L-IAS & - \\
Speed & $\mathrm{RPM}$ & Ambient temperature to 100 & 1 \\
Oil Temperature & ${ }^{\circ}$ & 10,000 & 0.5 \\
Maximum axial load & $\mathrm{N}$ & $100-4000$ & 0.5 \\
Scar range & $\mu \mathrm{m}$ & 12.7 & 0.5 \\
Test ball diameter & $\mathrm{mm}$ & 380/50/3/2000 & - \\
Power & $\mathrm{V} / \mathrm{Hz} / \mathrm{VA}$ & Microscope220 V, $50 \mathrm{~Hz}$ & - \\
Image measuring system & - & Web camera, $12 \mathrm{MP}$ & - \\
Image acquisition system & - & (Megapixels) & - \\
Software & - & Winducom 2010 & \\
\hline
\end{tabular}

Table 4. The specifications and operating parameters of the test and balls.

\begin{tabular}{ccc}
\hline Test Conditions & Units & Details \\
\hline Standard & - & ASTM D2266 [51] \\
Load & $\mathrm{kg}$ & $40,50,63$, and 80 \\
Speed & $\mathrm{rpm}$ & 1800 \\
Temperature of Fuel & ${ }^{\circ} \mathrm{C}$ & 27 \\
Test period & $\mathrm{s}$ & 300 \\
Test ball materials & - & Carbon-chromium steel (SKF) \\
Material composition & - & $0.12 \%$ P; $0.45 \% \mathrm{Si} ; 1.46 \%$ Cr; $0.06 \% \mathrm{Ni} ; 2.15 \% \mathrm{Zn} ;$ \\
Ball diameter & $\mathrm{mm}$ & $0.07 \%$ S; $0.42 \% \mathrm{Mn} ; 10.2 \%$; and $85.06 \%$ Fe; \\
Ball material hardness (HRc) & - & 12.7 \\
Ball material surface roughness & $\mu \mathrm{m}$ & 62 \\
\hline
\end{tabular}




\subsection{Test Method}

For the experiment's preparation on the four-ball tester, the cup of oil and four balls of steel were cleaned using acetone. Three balls of steel were fixed in the oil tub and secured as per the recommended torque, and then the testing oils were drained towards the oil tub till the three balls of steel were fully encased. One steel ball was grasped through a collet then attached to the instrument. This experiment used the ASTM standard D2266 [51], and its time period was $300 \mathrm{~s}$ with a constant speed of $1800 \mathrm{rpm}$, loads of $40,50,63$, and $80 \mathrm{~kg}$, and the oil's temperature at $27^{\circ} \mathrm{C}$. The values of different parameters were calculated and analysed by software. The four-ball tests' requirements are displayed in Table 4 . After the test was completed, the three balls from the cup were collected for the measurement of the wear surface's diameter through the optical microscope and the SEM study.

\subsubsection{Friction Assessment}

Winducom 2010 software was utilized to measure values of the mean friction coefficient. Additionally, it was calculated by Equation (1). With the load cell's usage in the instrument, the frictional torque was calculated (IP-239 standard, 1986 [54]). The same technique was also used by Habibullah et al. [32], Mosarof et al. [33], and Zulkifli et al. [55]. Where $\mu$ coefficient of friction, $T=$ frictional torque $(\mathrm{Nm}), W=\operatorname{load}(\mathrm{N})$, and $r=$ the distance measured between the contact surface centre on the lowest balls, and the axis of rotation is $3.67 \mathrm{~mm}$.

$$
\begin{gathered}
T=\frac{\mu \times r \times 3 W}{\sqrt{6}} \\
\mu=\frac{T \times \sqrt{6}}{r \times 3 W}
\end{gathered}
$$

\subsubsection{Wear Assessment}

According to the standard ASTM D4172 [52], the wear scar diameter of steel balls with the $0.01 \mathrm{~mm}$ resolution would be evaluated by an optical microscope. To capture the image of the wear scar, the optical microscope utilized the software in computer. Moreover, the wear scar diameter was calculated using the software, so this procedure was performed for every test of the fuel.

\subsubsection{Flash Temperature Parameter Assessment}

Equation (3) was used to measure the flash temperature parameter for all fuels. This is a vital factor for oils/lubricants when controlling the critical flash temperature while conducting the fourball test.

$$
\text { Flash temperature parameter }=\frac{F}{D^{1.4}}
$$

where, $F=$ load $(\mathrm{kg}), D=$ diameter of mean wear scar $(\mathrm{mm})$.

\section{Result and Discussion}

\subsection{Friction Performance}

At the start of the testing, the recorded friction behaviour was not stable because of the experiment's time interval. After a few seconds, the stabilized friction behaviour was recorded, also known as the steady-state condition. In the first $10 \mathrm{~s}$, the time interval coefficient of friction was displayed. The friction coefficient at the average steady-state of the last hundred seconds was collected and plotted to time in Figure 2. 

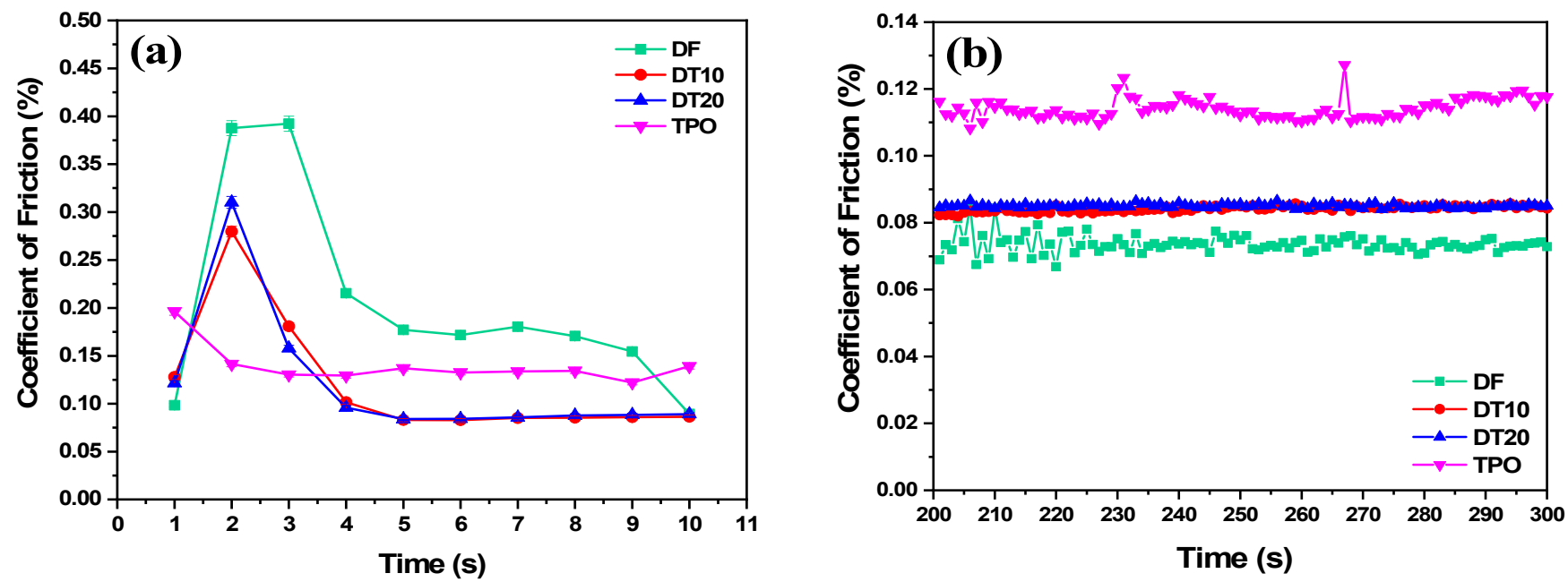

Figure 2. Diesel, TPO, and their blends' coefficient of friction performance with time; (a) Run-in period and (b) Steadystate condition.

Diesel fuel shows a higher coefficient of friction than other test fuel samples in the run-in period. The TPO and its blended samples generate better friction protection behaviour than diesel fuel. TPO, DT10, and DT20 display 49.9, 28.71 and 20.9\% lower unsteady coefficients of friction than diesel fuel. DT10 and DT20 show smooth behaviours of the steady-state coefficient of friction compared to pure diesel and TPO, which show fluctuating behaviours.

At the boundary lubrication condition as per the adopted testing conditions, the lubricating oil viscosity is the main factor that influences the thickness of the film dividing the surfaces and resultantly defines the behaviour of friction [56]. The viscosity of the lubricating oil is important. At the four-ball contact configuration, high temperatures were recorded, resulting in a decrease in oil viscosity and a higher average friction coefficient. Therefore, the comparison of friction profiles shows the poor friction behaviour of TPO. The comparative analysis of diesel-TPO and biodiesel-TPO blended fuels' coefficients of friction are shown in Figure 3 [31]. Biodiesel shows a better coefficient of friction than other fuels. It is mainly due to the higher viscosity and oxygen content in biodiesel [57].

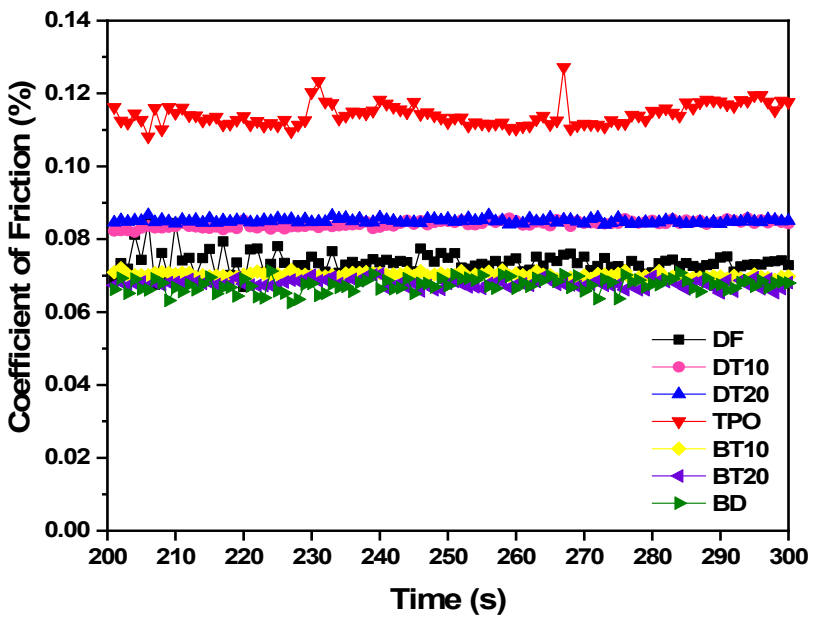

Figure 3. Comparative analysis of diesel-TPO and biodiesel-TPO blended fuels' coefficients of friction, this study with the literature [31].

\subsection{Wear Performance}

The wear of interacting tribo-pairs occurs when metal-to-metal interaction occurs at boundary lubrication conditions. The wear behaviour of all considered oils is shown in 
Figure 4 . The profiles clearly show that at low loads, i.e., 40, 50, and $63 \mathrm{~kg}$, TPO showed poor antiwear behaviour. However, TPO has shown better wear prevention at greater loads, i.e., $80 \mathrm{~kg}$. This trend also indicated TPO's high load-holding capability as considered to other considered samples. The ability to increase contact temperatures at higher loads resulted in slight viscous oil, which increased the chance of tribo-pair surface contact. DT10 showed better wear behaviour as compared to DF, TPO, and DT20 at low and high loads. The WSD of DT10, DT20, and TPO was 22.35, 16.01 and 31.99\%, respectively, less than diesel at the $80 \mathrm{~kg}$ load. TPO's high sulphur content decreases wear behaviour, and its association with diesel tends to boost lubricating properties [31,58]. Diesel has a low sulphur content, which causes lubricity concerns; however, Mello et al. [29] found that higher sulphur content increases lubricity. TPO has a higher load-carrying capacity, which indicates that it can handle heavier loads and be used in high-pressure situations [31]. Wear and friction between the surface contacts will minimize the amount of oxygen in biodiesel [33]. Thermal energy was produced in sliding contact surfaces, which the protective films were able to minimize, and the protective films increased the lubricity in this method [59]. The comparative analysis of the wear scar diameters of diesel-TPO and biodiesel-TPO blended fuel is shown in Figure 5 [31]. At higher loads, the TPO, DT10, and DT20 show better antiwear behaviour than the other fuels, and it is mainly due to the higher sulphur content in the TPO [29].

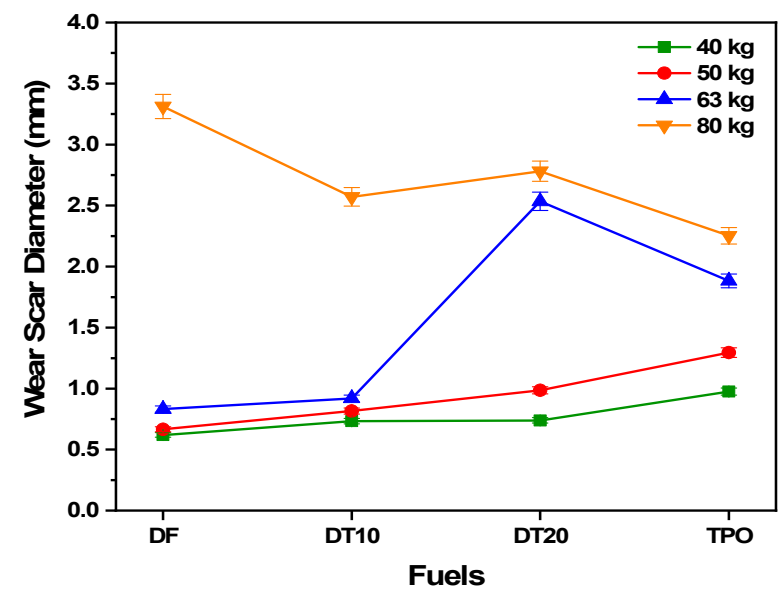

Figure 4. Diesel, TPO, and their blends' wear scar diameters at different loads.

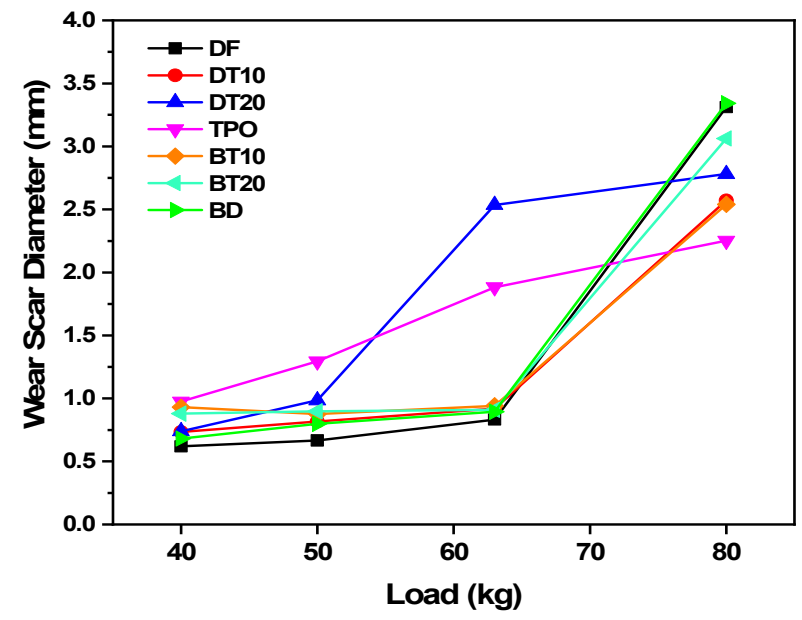

Figure 5. Comparative analysis of the wear scar diameters of diesel-TPO and biodiesel-TPO blended fuels, this study with the literature [31]. 


\subsection{Flash Temperature Parameter}

The effect of different fuels on flash temperature parameters under different temperatures is represented in Figure 6. The flash temperature parameter of different fuels decreases with the increase in the fuel's temperature. The flash temperature parameter is inversely proportional to the wear scar diameter. TPO shows the highest flash temperature parameter of $25.67^{\circ} \mathrm{C}$ at $80 \mathrm{~kg}$ load compared to other fuels. DT10 displays the better flash temperature parameter results, which are close to the diesel fuel at low loads. However, the lowest flash temperature parameter value is diesel fuel $\left(14.96^{\circ} \mathrm{C}\right)$. A higher flash temperature parameter level increases lubrication efficiency, whereas a lower flash temperature parameter level allows lubrication films to break down [60]. The oxidation process may affect lubricating performance [61]. TPO has a higher oxygen content as compared to diesel fuel [12]. Furthermore, the oxidation process provides improved lubricating efficiency outcomes in a limited time period [61]. The comparative analysis of flash temperature parameters of diesel-TPO and biodiesel-TPO blended fuel is shown in Figure 7 [31].

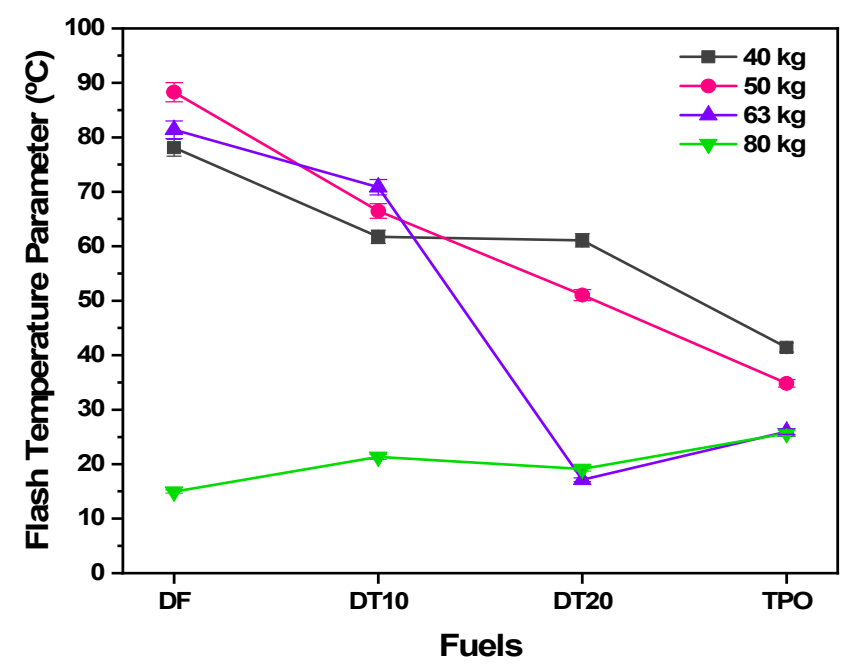

Figure 6. Diesel, TPO, and their blends' flash temperature parameter at different loads.

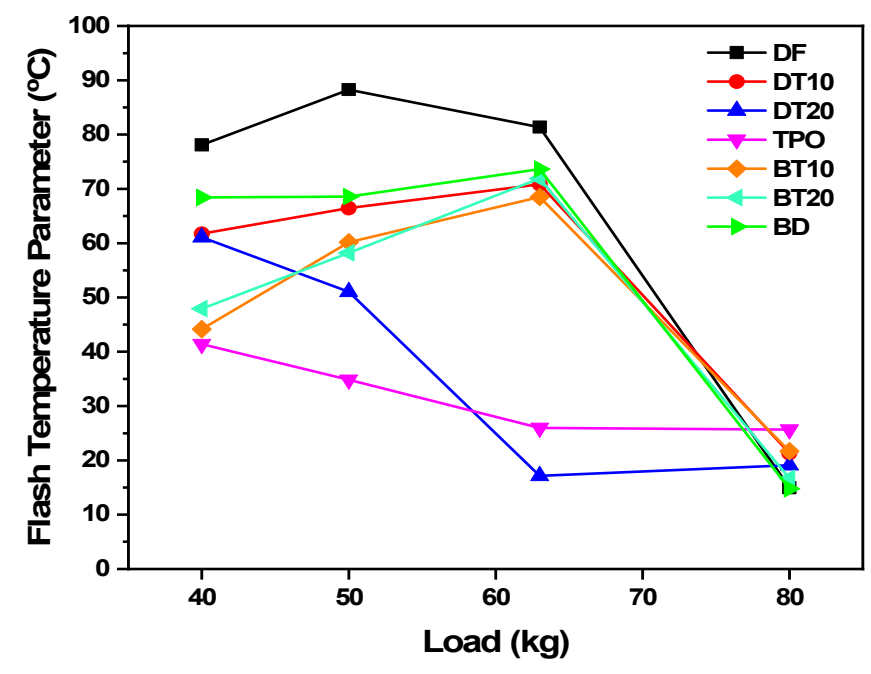

Figure 7. Comparative analysis of the flash temperature parameter of diesel-TPO and biodiesel-TPO blended fuel, this study with the literature [31]. 


\subsection{SEM Analysis}

To understand the antiwear behaviour of considered oil samples, tested balls' damaged interfaces were described using a scanning electron microscope (SEM). As TPO has depicted improved wear avoidance at greater load i.e., $80 \mathrm{~kg}$, the relevant worn surfaces were analysed using SEM. Figure 8a-i illustrates the SEM micrographs of the damaged interfaces of examined balls below $80 \mathrm{~kg}$ for tested fuel samples. Figure $8 \mathrm{a}-\mathrm{c}$ presents the micrographs of the DF, which shows adhesive wear and a rougher surface than those of the TPO sample (Figure $8 \mathrm{~d}-\mathrm{l}$ ). Similarly, Figure $8 \mathrm{~d}-\mathrm{f}$ shows less material removal than Figure $8 \mathrm{~g}-\mathrm{i}$, respectively. Figure $8 b, c, e, f, h, i, k, l$ show when the wear scar diameter tends to increase, there is an increment in the TPO blend ratio. TPO has higher oxygen and sulphur content. The oxidation process improves lubricating performance, while the higher sulphur content improves antiwear properties $[12,57,61]$.

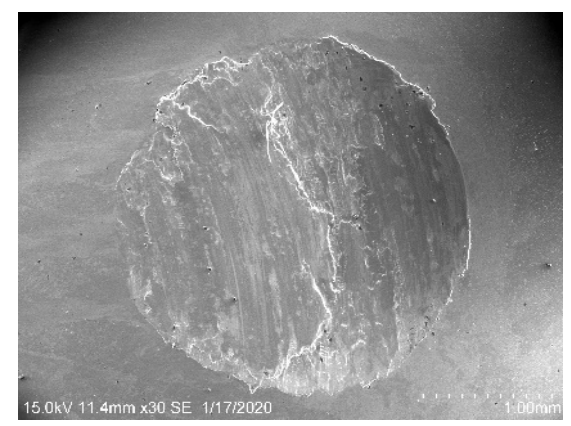

(a)

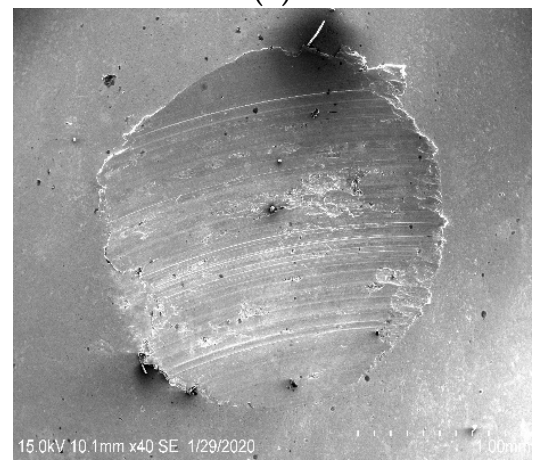

(d)

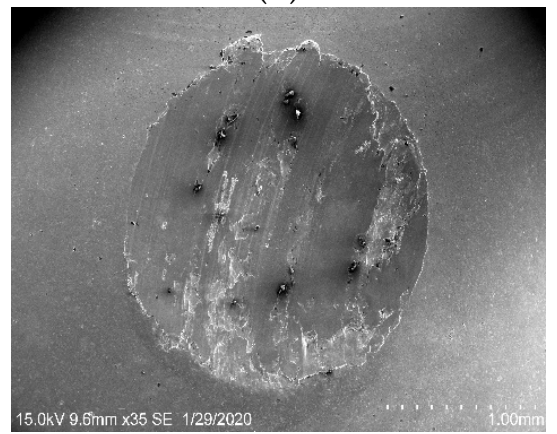

(g)

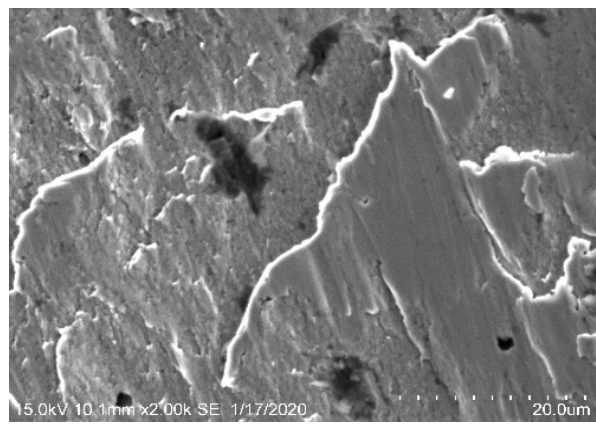

(b)

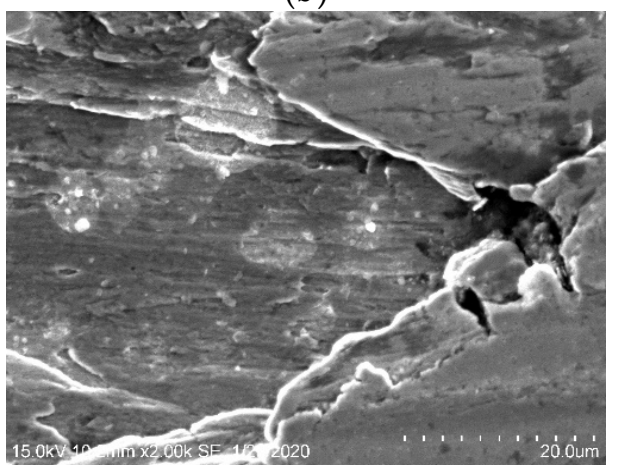

(e)

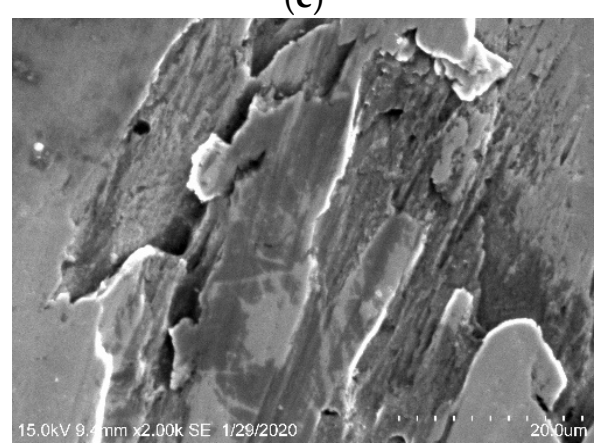

(h)

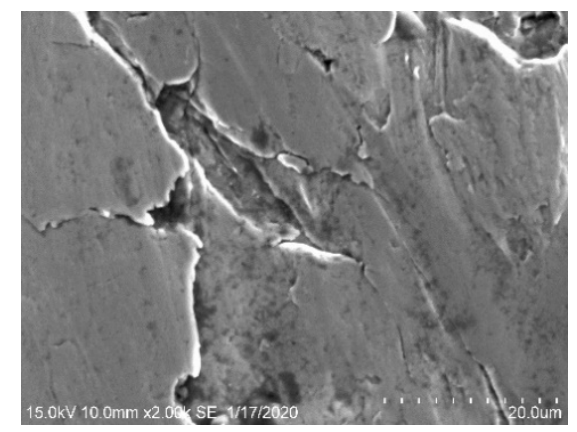

(c)

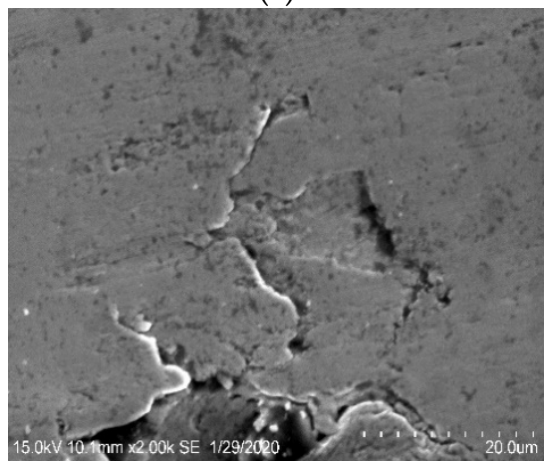

(f)

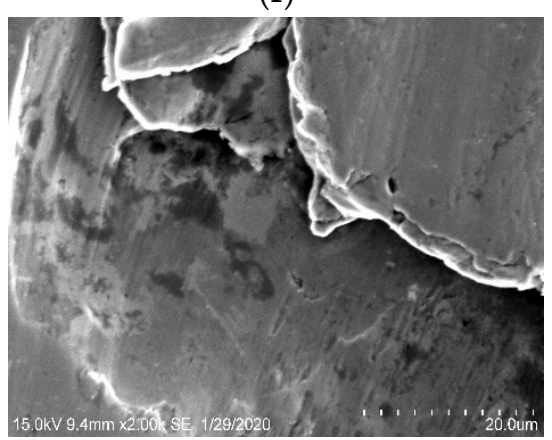

(i)

Figure 8. Cont. 


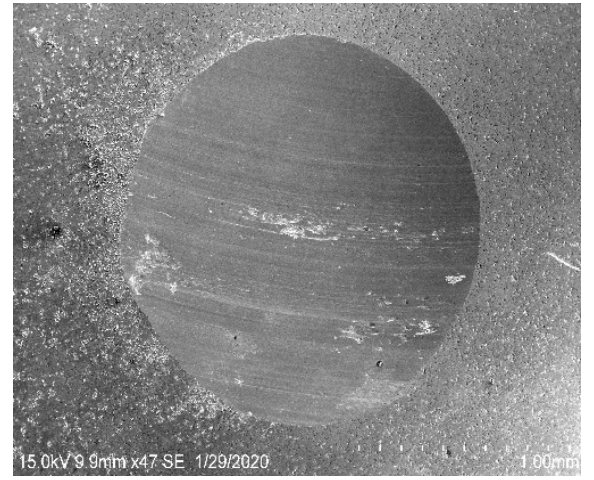

(j)

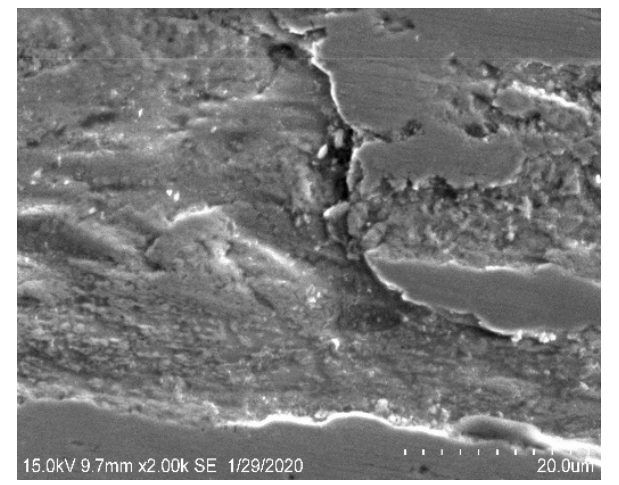

$(\mathbf{k})$

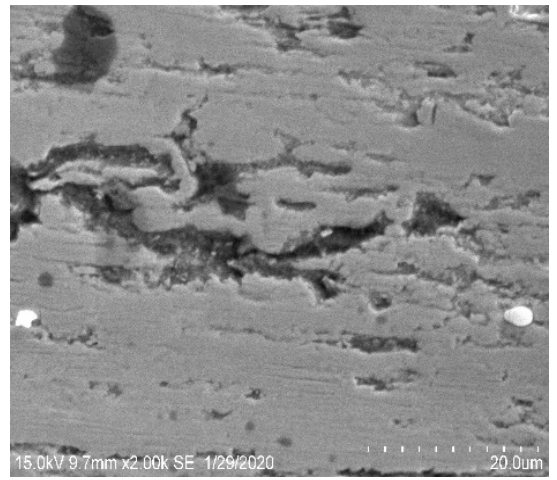

(1)

Figure 8. SEM analysis of the tested steel balls' worn surfaces at maximum load (80 kg). (a) DF-30x; (b) DF-2.00kx; (c) DF-2.00kx; (d) DT10-40x; (e) DT10-2.00kx; (f) DT10-2.00kx; (g) DT20-40x; (h) DT20-2.00kx; (i) DT20-2.00kx; (j) TPO-47x; (k) TPO-2.00kx and (l) TPO-2.00kx.

\section{Conclusions}

This experimental research used a four-ball tester to identify the tribological performance of TPO blended with DF. All tested fuels were tested for $300 \mathrm{~s}$ at 40, 50, 63, and $80 \mathrm{~kg}$ loads, at a constant speed $(1800 \mathrm{rpm})$, and the same temperature $\left(27^{\circ} \mathrm{C}\right)$ using the ASTM D2266 standard [51]. The TPO's tribological performance was compared to that of the DT10 (TPO 10\%, Diesel 90\%) and DT20 (TPO 20\%, Diesel 80\%) diesel fuels. The four-ball tribometer is a common research rig used in the lubricant industry to assist in manufacturing new lubricants and greases. So, it was used to research the tribological performance of the diesel fuel blend with TPO. The significant conclusions of this research are as follows:

- Diesel fuel showed $49.9 \%, 28.71 \%$, and $20.9 \%$ higher unsteady friction coefficients than TPO, DT10, and DT20, respectively. DT10 and DT20 displayed smooth behaviour of the steady-state friction coefficient compared to diesel's fluctuating performance.

- DT10 exhibited better wear behaviour relative to diesel, TPO, and DT20 at low and high loads. The WSD of DT10, DT20, and TPO were 22.35, 16.01, and 31.99\%, respectively, smaller than diesel at the load of $80 \mathrm{~kg}$.

- TPO showed a higher load-carrying capacity, which shows its potential to use at higher loads and in extreme pressure conditions.

- The wear behaviours of considered blends showed that a reasonable friction behaviour and a greater load-holding capability could be obtained for a specific use.

- $\quad$ TPO displayed the highest flash temperature parameter of $25.67{ }^{\circ} \mathrm{C}$ at $80 \mathrm{~kg}$ load compared to other fuels. DT10 displayed the better flash temperature parameter results, close to the diesel fuel at low loads. However, the lowest flash temperature parameter value was credited to diesel fuel $\left(14.96^{\circ} \mathrm{C}\right)$.

- The SEM micrographs revealed that the TPO and DT10 display lower metal extrusion than DT20 and diesel fuel.

The research outcome recommends that in aspects of wear and friction, DT10 displays favourable tribological results. Therefore, it can be utilized to improve its life in the engine.

Author Contributions: Conceptualization, Y.H.T., F.S., M.A.J., M.N. and O.R.; data curation, H.Y. and B.E.; formal analysis, H.Y., M.A.J., O.R. and B.E.; funding acquisition, F.S. and M.A.J.; investigation, H.Y., F.S., M.N. and O.R.; methodology, H.Y., Y.H.T., M.A.J., O.R. and B.E.; project administration, Y.H.T., F.S. and M.N.; resources, H.Y., Y.H.T., F.S., M.N. and O.R.; software, H.Y., M.A.J., O.R. and B.E.; supervision, Y.H.T. and F.S.; validation, H.Y. and O.R.; visualization, H.Y., F.S., M.N. and O.R.; writing-original draft, H.Y., F.S., M.A.J., M.N., O.R. and B.E.; writing—review \& editing, Y.H.T., F.S., M.N. and B.E. All authors have read and agreed to the published version of the manuscript. 
Funding: This research was funded by the Ministry of Higher Education (MOHE) of Malaysia (Fundamental Research Grant Scheme (FRGS)-203.PMEKANIK.6071444).

Institutional Review Board Statement: Not applicable.

Informed Consent Statement: Not applicable.

Data Availability Statement: Data sharing not applicable.

Acknowledgments: The authors would like to acknowledge the Universiti Sains Malaysia for financial support toward this study.

Conflicts of Interest: The authors declare that they have no known competing financial interests or personal relationships that could have appeared to influence the work reported in this paper.

$\begin{array}{ll}\text { Abbreviations } \\ \text { ASTM } & \text { American society for testing and materials } \\ \text { BD } & \text { Biodiesel } \\ \text { BT10 } & \text { TPO 10\%, Biodiesel 90\% } \\ \text { BT20 } & \text { TPO 20\%, Biodiesel } 80 \% \\ \text { CIB } & \text { Calophyllum inophyllum biodiesel } \\ \text { CI } & \text { Compression ignition } \\ \text { COF } & \text { Coefficient of friction } \\ \text { DF } & \text { Diesel fuel } \\ \text { DT10 } & \text { TPO 10\%, Diesel 90\% } \\ \text { DT20 } & \text { TPO 20\%, Diesel 80\% } \\ \text { EDX } & \text { Energy dispersive X-ray } \\ \text { EU } & \text { European Union } \\ \text { FBT } & \text { Four ball tribometer } \\ \text { FTP } & \text { Flash temperature parameter } \\ \text { GC-MS } & \text { Gas chromatography-mass spectroscopy } \\ \text { MO } & \text { Mongongo-oil } \\ \text { PB } & \text { Palm oil biodiesel } \\ \text { PCT } & \text { Passenger car type } \\ \text { SEM } & \text { Scanning electron microscope } \\ \text { TPO } & \text { Tire pyrolysis oil } \\ \text { TT } & \text { Truck tire } \\ \text { WSD } & \text { Wear scar diameter }\end{array}$

\section{References}

1. Yaqoob, H.; Teoh, Y.H.; Jamil, M.A.; Gulzar, M. Potential of tire pyrolysis oil as an alternate fuel for diesel engines: A review. J. Energy Inst. 2021, 96, 1-17. [CrossRef]

2. Rashid, T.; Ali, S.; Taqvi, A.; Sher, F.; Rubab, S.; Thanabalan, M.; Bilal, M. Enhanced lignin extraction and optimisation from oil palm biomass using neural network modelling. Fuel 2021, 293, 120485. [CrossRef]

3. Sher, F.; Yaqoob, A.; Saeed, F.; Zhang, S.; Jahan, Z.; Klemeš, J.J. Torrefied biomass fuels as a renewable alternative to coal in co-firing for power generation. Energy 2020, 209, 118444. [CrossRef]

4. Murugesan, A.; Umarani, C.; Subramanian, R.; Nedunchezhian, N. Bio-diesel as an alternative fuel for diesel engines-A review. Renew. Sustain. Energy Rev. 2009, 13, 653-662. [CrossRef]

5. Dhar, A.; Agarwal, A.K. Performance, emissions and combustion characteristics of Karanja biodiesel in a transportation engine. Fuel 2014, 119, 70-80. [CrossRef]

6. Yaqoob, H.; Teoh, Y.H.; Goraya, T.S.; Sher, F.; Jamil, M.A.; Rashid, T.; Yar, K.A. Energy evaluation and environmental impact assessment of transportation fuels in Pakistan. Case Stud. Chem. Environ. Eng. 2021, 3, 100081. [CrossRef]

7. Qaisrani, M.A.; Wei, J.; Khan, L.A. Potential and transition of concentrated solar power: A case study of China. Sustain. Energy Technol. Assess. 2021, 44, 101052. [CrossRef]

8. Lam, M.K.; Tan, K.T.; Lee, K.T.; Mohamed, A.R. Malaysian palm oil: Surviving the food versus fuel dispute for a sustainable future. Renew. Sustain. Energy Rev. 2009, 13, 1456-1464. [CrossRef]

9. Duan, P.; Jin, B.; Xu, Y.; Wang, F. Co-pyrolysis of microalgae and waste rubber tire in supercritical ethanol. Chem. Eng. J. 2015, 269, 262-271. [CrossRef]

10. Yaqoob, H.; Teoh, Y.H.; Sher, F.; Jamil, M.A.; Murtaza, D.; Al Qubeissi, M.; Hassan, M.U.I.; Mujtaba, M.A. Current status and potential of tire pyrolysis oil production as an alternative fuel in developing countries. Sustainability 2021, 13, 3214. [CrossRef] 
11. Mokhtar, N.M.; Omar, R.; Idris, A. Microwave pyrolysis for conversion of materials to energy: A brief review. Energy Sources Part A Recovery Util. Environ. Eff. 2012, 34, 2104-2122. [CrossRef]

12. Verma, P.; Zare, A.; Jafari, M.; Bodisco, T.A.; Rainey, T.; Ristovski, Z.D.; Brown, R.J. Diesel engine performance and emissions with fuels derived from waste tyres. Sci. Rep. 2018, 8, 2457. [CrossRef]

13. Ameen, M.; Zamri, N.M.; May, S.T.; Azizan, M.T.; Aqsha, A.; Sabzoi, N.; Sher, F. Effect of acid catalysts on hydrothermal carbonization of Malaysian oil palm residues (leaves, fronds, and shells) for hydrochar production. Biomass Convers. Biorefinery 2021. [CrossRef]

14. Al-Juboori, O.; Sher, F.; Hazafa, A.; Khan, M.K.; Chen, G.Z. The effect of variable operating parameters for hydrocarbon fuel formation from $\mathrm{CO}_{2}$ by molten salts electrolysis. J. CO2 Util. 2020, 40, 101193. [CrossRef]

15. Zhang, Y.; Ran, Z.; Jin, B.; Zhang, Y.; Zhou, C.; Sher, F. Simulation of particle mixing and separation in multi-component fluidized bed using Eulerian-Eulerian method: A review. Int. J. Chem. React. Eng. 2019, 17, 1-27. [CrossRef]

16. ACEA. ACEA Pocket Guide_European Automobile Manufacturers' Association; ACEA: Brussels, Belgium, 2016.

17. Voelcker, J. 1.2 Billion Vehicles on World's Roads Now, 2 Billion by 2035: Report. Available online: https:/ / www.greencarreports. com/news/1093560_1-2-billion-vehicles-on-worlds-roads-now-2-billion-by-2035-report (accessed on 18 October 2018).

18. Shulman, V.L. Tyre Recycling, Rapra Review Reports; Smithers Rapra Press: Shrewsbury, UK, 2004.

19. Li, W.; Huang, C.; Li, D.; Huo, P.; Wang, M.; Han, L.; Chen, G.; Li, H.; Li, X.; Wang, Y.; et al. Derived oil production by catalytic pyrolysis of scrap tires. Chin. J. Catal. 2016, 37, 526-532. [CrossRef]

20. Khan, M.Z.; Hossain, M.I.; Halder, P.K.; Hasan, M.R.; Al-Mamun, M.R. Fuel properties of pyrolytic tyre oil and its blends with diesel fuel-Towards waste management. Int. J. Environ. Waste Manag. 2016, 18, 335-348. [CrossRef]

21. García-Contreras, R.; Martínez, J.D.; Armas, O.; Murillo, R.; García, T. Study of a residential boiler under start-transient conditions using a tire pyrolysis liquid (TPL)/diesel fuel blend. Fuel 2015, 158, 744-752. [CrossRef]

22. Pinto, G.M.; De Souza, T.A.Z.; Coronado, C.J.R.; Flôres, L.F.V.; Chumpitaz, G.R.A.; Silva, M.H. Experimental investigation of the performance and emissions of a diesel engine fuelled by blends containing diesel S10, pyrolysis oil from used tires and biodiesel from waste cooking oil. Environ. Prog. Sustain. Energy 2019, 38, 13199. [CrossRef]

23. Karagoz, M.; Uysal, C.; Agbulut, U.; Saridemir, S. Energy, exergy, economic and sustainability assessments of a compression ignition diesel engine fueled with tire pyrolytic oil-diesel blends. J. Clean. Prod. 2020, 264, 121724. [CrossRef]

24. Pote, R.N.; Patil, R.K. Combustion and emission characteristics analysis of waste tyre pyrolysis oil. Sn Appl. Sci. 2019, 294. [CrossRef]

25. Uyumaz, A.; Aydoğan, B.; Solmaz, H.; Yılmaz, E.; Hopa, D.Y.; Bahtli, T.A.; Solmaz, Ö.; Aksoy, F. Production of waste tyre oil and experimental investigation on combustion, engine performance and exhaust emissions. J. Energy Inst. 2019, 92, 1406-1418. [CrossRef]

26. Sharma, A.; Murugan, S. Potential for using a tyre pyrolysis oil-biodiesel blend in a diesel engine at different compression ratios. Energy Convers. Manag. 2015, 93, 289-297. [CrossRef]

27. Singh, D.; Soni, S.L.; Sharma, D.; Kumari, D. Waste tyre oil as alternative fuel in CI engine: A review. Int. J. Adv. Res. Innov. Ideas Educ. 2017, 3, 577-585.

28. Quek, A.; Balasubramanian, R. Liquefaction of waste tires by pyrolysis for oil and chemicals-A review. J. Anal. Appl. Pyrolysis 2013, 101, 1-16. [CrossRef]

29. Silva e Mello, V.; Do Vale Souza, E.R.; De Araújo Oliveira, M.V.; Alves, S.M. Effect of desulfurization of diesel and its blends with biodiesel on metallic contact. Mater. Res. 2014, 17, 82-88. [CrossRef]

30. Murugan, S.; Sundaramoorthi, H.; Nagarajan, G.; Horak, B. A comparative study on some methods to use tyre pyrolysis oil as an alternative fuel in a DI diesel engine. In Exergy for A Better Environment and Improved Sustainability 2: Applications; Aloui, F., Dincer, I., Eds.; Springer International Publishing: Cham, Switzerland, 2018; pp. 405-420. ISBN 978-3-319-62575-1.

31. Yaqoob, H.; Teoh, Y.H.; Jamil, M.A.; Rasheed, T.; Sher, F. An experimental investigation on tribological behaviour of tire-derived pyrolysis oil blended with biodiesel fuel. Sustainability 2020, 12, 9975. [CrossRef]

32. Habibullah, M.; Masjuki, H.H.; Kalam, M.A.; Zulkifli, N.W.; Masum, B.M.; Arslan, A.; Gulzar, M. Friction and wear characteristics of Calophyllum inophyllum biodiesel. Ind. Crop. Prod. 2015, 76, 188-197. [CrossRef]

33. Mosarof, M.H.; Kalam, M.A.; Masjuki, H.H.; Alabdulkarem, A.; Habibullah, M.; Arslan, A.; Monirul, I.M. Assessment of friction and wear characteristics of Calophyllum inophyllum and palm biodiesel. Ind. Crop. Prod. 2016, 83, 470-483. [CrossRef]

34. Mujtaba, M.A.; Muk Cho, H.; Masjuki, H.H.; Kalam, M.A.; Farooq, M.; Soudagar, M.E.M.; Gul, M.; Ahmed, W.; Afzal, A.; Bashir, S.; et al. Effect of alcoholic and nano-particles additives on tribological properties of diesel-palm-sesame-biodiesel blends. Energy Rep. 2020, 7, 1162-1171. [CrossRef]

35. Sharul, M.; Awang, N.; Wahidah, N.; Zulkifli, M.; Abbass, M.M.; Zulkifli, S.A.; Nur, M.; Mohd, A. Effect of blending local plastic pyrolytic oil with diesel fuel on lubricity. J. Tribol. 2020, 27, 143-157.

36. ASTM D6079-18, Standard Test Method for Evaluating Lubricity of Diesel Fuels by the High-Frequency Reciprocating Rig (HFRR); ASTM International: West Conshohocken, PA, USA, 2018.

37. Chauhan, B.S.; Kumar, N.; Cho, H.M. A study on the performance and emission of a diesel engine fueled with Jatropha biodiesel oil and its blends. Energy 2012, 37, 616-622. [CrossRef] 
38. Fayaz, H.; Mujtaba, M.A.; Soudagar, M.E.M.; Razzaq, L.; Nawaz, S.; Nawaz, M.A.; Farooq, M.; Afzal, A.; Ahmed, W.; Khan, T.M.Y.; et al. Collective effect of ternary nano fuel blends on the diesel engine performance and emissions characteristics. Fuel 2021, 293, 120420. [CrossRef]

39. Tung, S.C.; McMillan, M.L. Automotive tribology overview of current advances and challenges for the future. Tribol. Int. 2004, 37, 517-536. [CrossRef]

40. Serrano, L.M.; Câmara, R.M.; Carreira, V.J.; Da Silva, M.G. Performance study about biodiesel impact on buses engines using dynamometer tests and fleet consumption data. Energy Convers. Manag. 2012, 60, 2-9. [CrossRef]

41. Sarvi, A.; Fogelholm, C.-J.; Zevenhoven, R. Emissions from large-scale medium-speed diesel engines: 2 . Influence of fuel type and operating mode. Fuel Process. Technol. 2008, 89, 520-527. [CrossRef]

42. Thangavelu, S.K.; Arthanarisamy, M. Experimental investigation on engine performance, emission, and combustion characteristics of a DI CI engine using tyre pyrolysis oil and diesel blends doped with nanoparticles. Environ. Prog. Sustain. Energy 2020, 39, 1-7. [CrossRef]

43. Vihar, R.; Seljak, T.; Rodman Oprešnik, S.; Katrašnik, T. Combustion characteristics of tire pyrolysis oil in turbo charged compression ignition engine. Fuel 2015, 150, 226-235. [CrossRef]

44. Hamzah, M.H.; Alias, A.; Mamat, R.; Abdullah, A.A.; Sudrajad, A.; Ramlan, N.A.; Jaharudin, N.F. Performance analysis of diesel engine running with tyre-derived fuel. Iop Conf. Ser. Mater. Sci. Eng. 2019, 469, 12017. [CrossRef]

45. Hürdoğan, E.; Ozalp, C.; Kara, O.; Ozcanli, M. Experimental investigation on performance and emission characteristics of waste tire pyrolysis oil-diesel blends in a diesel engine. Int. J. Hydrogen Energy 2017, 42, 23373-23378. [CrossRef]

46. Murillo, R.; Aylo, E.; Navarro, M.V.; Calle, M.S.; Aranda, A.; Mastral, A.M. The application of thermal processes to valorise waste tyre. Fuel Process. Technol. 2006, 87, 143-147. [CrossRef]

47. Frigo, S.; Seggiani, M.; Puccini, M.; Vitolo, S. Liquid fuel production from waste tyre pyrolysis and its utilisation in a diesel engine. Fuel 2014, 116, 399-408. [CrossRef]

48. ASTM D240-19, Standard Test Method for Heat of Combustion of Liquid Hydrocarbon Fuels by Bomb Calorimeter; ASTM International: West Conshohocken, PA, USA, 2019.

49. ASTM D7042-21, Standard Test Method for Dynamic Viscosity and Density of Liquids by Stabinger Viscometer (and the Calculation of Kinematic Viscosity); ASTM International: West Conshohocken, PA, USA, 2021.

50. ASTM D4052-18a, Standard Test Method for Density, Relative Density, and API Gravity of Liquids by Digital Density Meter; ASTM International: West Conshohocken, PA, USA, 2018.

51. ASTM D2266-01, Standard Test Method for Wear Preventive Characteristics of Lubricating Grease (Four-Ball Method); ASTM International: West Conshohocken, PA, USA, 2015.

52. ASTM D4172-20, Standard Test Method for Wear Preventive Characteristics of Lubricating Fluid (Four-Ball Method); ASTM International: West Conshohocken, PA, USA, 2020.

53. ASTM F1372-93, Standard Test Method for Scanning Electron Microscope (SEM) Analysis of Metallic Surface Condition for Gas Distribution System Components; ASTM International: West Conshohocken, PA, USA, 2020.

54. IP-239, Determination of Extreme Pressure and Anti-Wear Properties of Lubricating Fluids and Greases-Four Ball Method (European Conditions); Energy Institute: London, UK, 1986.

55. Zulkifli, N.W.M.; Kalam, M.A.; Masjuki, H.H.; Al Mahmud, K.A.H.; Yunus, R. The effect of palm oil trimethylolpropane ester on extreme pressure lubrication. Proc. Inst. Mech. Eng. Part J J. Eng. Tribol. 2014, 228, 160-169. [CrossRef]

56. Zulkifli, N.W.M.; Azman, S.S.N.; Kalam, M.A.; Masjuki, H.H.; Yunus, R.; Gulzar, M. Lubricity of bio-based lubricant derived from different chemically modified fatty acid methyl ester. Tribol. Int. 2016, 93, 555-562. [CrossRef]

57. Wain, K.S.; Perez, J.M.; Chapman, E.; Boehman, A.L. Alternative and low sulfur fuel options: Boundary lubrication performance and potential problems. Tribol. Int. 2005, 38, 313-319. [CrossRef]

58. Nikanjam, M.; Henderson, P.T. Lubricity of low sulfur diesel fuels. SAE Tech. Pap. 1993, 1-9. [CrossRef]

59. Knothe, G.; Steidley, K.R. Kinematic viscosity of biodiesel fuel components and related compounds. Influence of compound structure and comparison to petrodiesel fuel components. Fuel 2005, 84, 1059-1065. [CrossRef]

60. Habibullah, M.; Masjuki, H.H.; Kalam, M.A.; Gulzar, M.; Arslan, A.; Zahid, R. Tribological characteristics of calophyllum inophyllum-based TMP (trimethylolpropane) ester as energy-saving and biodegradable lubricant. Tribol. Trans. 2015, 58, 1002-1011. [CrossRef]

61. Tsuchiya, T.; Shiotani, H.; Goto, S.; Sugiyama, G.; Maeda, A. Japanese standards for diesel fuel containing 5\% fame: Investigation of acid generation in fame blended diesel fuels and its impact on corrosion. SAE Tech. Pap. 2006, 776-790. [CrossRef] 